\title{
Effect of urban compost, sewage sludge, poultry manure and fertilizers on soil fertility improvement and fruit yield of brinjal (Solanum melongena L.)
}

\section{R. SAIKUMAR AND K. JEEVAN RAO}

Received : 04.02.2017; Revised : 01.05.2017; Accepted : 15.05.2017

\section{MEMBERS OF RESEARCH FORUM:}

Corresponding author :

R.SAIKUMAR, Department of Soil Science, College of Agriculture, Prof Jayashankar Telangana State Agricultural University,

Rajendranagar, HYDERABAD (TELANGANA) INDIA

Email: saikumaragrico@gmail.com

Co-authors :

K. JEEVAN RAO, Department of Soil Science, College of Agriculture, Prof. Jayashankar Telangana State Agricultural University,

Rajendranagar, HYDERABAD ( TELANGANA) INDIA

\section{Summary}

Field experiment was carried out at College Farm, College of Agriculture, Rajendranagar, Hyderabad to determine the effect of sewage sludge, urban compost, poultry manure and fertilizers on the soil fertility improvement and fruit yield of brinjal in 2013 Kharif season. The three organic manures were applied each at 2.5and 5.0 t/ha, 100\%RDF and combination of fertilizer levels (75\% RDF) with manures at different levels and a control treatment, arranged in a Randomized Block Design (RBD) with three replicates. The results showed significant increase in the fruit yield of brinjal crop under integrated treatments compared to control treatment. The application of poultry manure @ $5.0 \mathrm{t}$ / ha along with 75\% RDF resulted in the highest fruit yield of brinjal (33.6) followed by sewage sludge @ $5.0 \mathrm{t}$ / ha along with 75\% RDF (32.5). The highest values of organic carbon, available nitrogen, phosphorus and potassium were obtained under poultry manure @ 5.0 t/ ha along with 75\% RDF.

Key words : Brinal, Fruit yield, Organic manures, Fertilizers, Soil fertility

How to cite this article : Saikumar, R. and Rao, K. Jeevan (2017). Effect of urban compost, sewage sludge, poultry manure and fertilizers on soil fertility improvement and fruit yield of brinjal (Solanum melongena L.). Asian J. Soil Sci., 12 (1) : 151-156 : DOI : 10.15740/HAS/AJSS/12.1/151-156. 